\title{
Audio-Visual Aids in the Teaching of Psychiatry
}

(Notes from a contribution to the Ninth Tutors' Conference)

'Throughout the ages the problem has always been how to get communication out of information'.

Peter Druker

One of the first recorded teaching films on psychiatry was 'Conditioned Reflexes' made in the USSR, still praised in film catalogues of the late 60s. Henry Leymann was another early pioneer in Montreal. Benefiting from the post-war emigration of documentary talent from the British Crown Film Unit, he made a number of classic teaching films including the 'Mental Mechanisms' series (1946-50) and the 'Mental Symptoms' series (1951). Also from Canada came the 'Ages and Stages' series in the early 1950s and the 'Disordered Mind' case histories in 1961. These were all films of their time, of considerable archival value, as was 'Out of True', made at Netherne Hospital in 1951.

Others were exploring new uses for film in psychiatry; Margaret Mead ('Childhood Rivalry in Bali and New Guinea' and 'Bathing Babies in Three Cultures'-1950), Edward Mason at the Harvard School of Community Psychiatry (1960), and Professor Kamp's comparative case history study of twins (Autistic Syndrome 1, 2, 3 etcUtrecht 1961).

The RMPA Films Sub-Committee was formed in 1957 by Jonathan Gould, with Stanley Thorley and the late Helen Coppen effecting a link with the British Universities Film Council. The 'RMPA Collection' in the BMA Film Library (still in demand) was made in 1962-'Group Psychotherapy', 'Huntington's Chorea', 'Paraphrenia' and 'The Subnormality Picture'-at an average cost of $£ 500$ for each film.

In association with the Scientific Film Association, the RMPA published the first UK catalogue, with appraisals, in the late 1950s, although the World Federation for Mental Health had brought out an international catalogue some years earlier. Other developments at this time were the formation of the BMA Film Library, the setting up of the Concord Film Council by Lydia Vulliamy and Eric Walker in 1959, and the establishment of the Mental Health Film Council, administrated by Margaret Mawer, in 1963.

In 1960 Drs John and Valerie Graves foresaw the application of tape-slide programmes to medical teaching and founded what is now called the Graves Audio-Visual Library, with which the College is presently co-operating over programmes on psychotherapy and epidemiology. Another development, pioneered in Edinburgh, was the making of tape-slide programmes on various projects as a learning process in itself.

An early educational TV programme on psychiatry was the BBC's 'Hurt Mind' series in 1957, in which actual patients were shown for the first time, although the participants were still guardedly referred to as 'A Physician
Superintendent', etc. The use of video-tapes for higher education was developed at the Universities Film Centre in Utrecht in association with Messrs Philips, and the following twenty years have seen the rapid development of very competitive hardware in this field. Video-recording is now a major activity of university A-V departments, and hardly any hospital is without access to recording and play-back facilities.

The comparative ease with which picture and sound can be recorded and immediately played back had prompted tutors and others to look for teaching and research applications. Many are distracted, however, by rapidly changing technicalities and incompatibilities of the systems, and one function of the College's Audio-Visual Sub-Committee is to devise means of bridging the gap between psychiatric education and the A-V industry. To this end it organized a workshop at the National Audio-Visual Aids Centre last year, and a practical demonstration by Messrs. Saville of York at this years tutors' conference.

At this time of financial stringency it might be worth while to recall the remark of Derek Bok of Harvard-'If you think education is expensive, try ignorance'. The use of audiovisual teaching material need not be costly, however, as an increasing number of programmes are available for comparatively inexpensive outright purchase as videotapes and tape-slide sets. The following sources together offer a wide range of psychiatric teaching materials:

Concord Films Council Lid., 201 Felixstowe Road, Ipswich, Suffolk 1P3 9BJ. Phone 76012. (Catalogue and library)

Mental Health Film Council, 22 Harley Street, London WIN 2ED. Phone 637-0741 (Catalogue)

BMA Film Library, British Medical Association, BMA House, Tavistock Square, London WC1H 9JP. Phone 387-4499. (Catalogue and library)

BBC Enterprises Ltd., Woodston House, Oundle Road, Peterborough PE2 9PZ. Phone 52257. (Catalogue and library, also sales)

British Universities Film Council, 81 Dean Street, London WIV 6AA. Phone 734-3687 (Catalogues)

Open University Educational Enterprises Ltd., 12 Cofferidge Close, Stony Stratford, Milton Keynes MK11 1BY. Phone 566744. (Catalogue and library)

Viscom Audio-Visual Library, Unit B11, Parkhall Road, Trading Estate, London SE21 8EL. Phone 670-6161. (Catalogue and library - social studies section)

Graves Medical Audio-Visual Library, P.0. Box 99, Chelmsford, Essex CM2 9BJ. Phone 83351. (Catalogue, library and tape-slide programmes)

Camera Talks, 31 North Row, London WIR 2EN. Phone 493 2761. (Catalogue and sales and tape-slide programmes)

Oxford Educational Resources Ltd., Botley Road, Oxford OX2 OHE. Phone 41474. (Catalogue, sales and tape-slide programmes)

Tom Pinkington 